\title{
PENGARUH MODEL QUANTUM TEACHING BERBANTUAN MULTIMEDIA INTERAKTIF TERHADAP KETERAMPILAN MENULIS
}

\author{
Ni Putu Elfira Sari \\ Jurusan Pendidikan Dasar, Universitas Pendidikan Ganesha, Singaraja, Indonesia \\ sari.ni.putu@undiksha.ac.id
}

I Ketut Adnyana Putra

Jurusan Pendidikan Dasar, Universitas Pendidikan Ganesha, Singaraja, Indonesia ketut.adnyana.putra@undiksha.ac.id

Rini Kristiantari

Jurusan Pendidikan Dasar, Universitas Pendidikan Ganesha, Singaraja, Indonesia mariagoretirini.kristiantari@undiksha.ac.id

\begin{abstract}
Abstrak
Penelitian ini bertujuan untuk mengetahui perbedaan yang signifikan keterampilan menulis antara kelompok siswa yang belajar dengan menggunakan model quantum teaching berbantuan multimedia interaktif dan siswa yang belajar dengan menggunakan pembelajaran konvensional. Jenis penelitian yang digunakan yaitu eksperimen semu dengan desain nonequivalent control group design. Populasi penelitian meliputi seluruh kelas V SDN Gugus V Jenderal Sudirman Kecamatan Denpasar Selatan pada semester genap sebanyak 331 siswa. Sampel penelitian ditentukan dengan teknik random sampling. Sampel dalam penelitian ini adalah kelas VA SDN 6 Sesetan sebanyak 45 siswa sebagai kelompok eksperimen dan kelas V SDN 2 Serangan sebanyak 38 siswa sebagai kelompok kontrol. Data penelitian dikumpulkan dengan metode tes isian. Data yang terkumpul dianalisis dengan uji-t. Hasil analisis data pada taraf signifikansi $5 \%$ (dk=81 dengan $t_{\text {hitung }}=3,70$ dan $t_{\text {tabel }}=2,00$ ) yaitu Ho ditolak, dan rata-rata nilai siswa yang belajar dengan menggunakan model quantum teaching berbantuan multimedia interaktif, yaitu 80,24 dan siswa yang belajar dengan menggunakan pembelajaran konvensional, yaitu 74,84. Maka terdapat perbedaan yang signifikan keterampilan menulis antara kelompok siswa yang belajar dengan menggunakan model quantum teaching berbantuan multimedia interaktif dan siswa yang belajar dengan menggunakan pembelajaran konvensional. Dengan demikian, dapat disimpulkan model quantum teaching berbantuan multimedia interaktif berpengaruh terhadap keterampilan menulis siswa kelas V SDN Gugus V Jenderal Sudirman Kecamatan Denpasar Selatan tahun ajaran 2018/2019.
\end{abstract}

Kata Kunci: Quantum Teaching, Keterampilan Menulis, Multimedia.

\begin{abstract}
This study aims to determine the significant differences in writing skills between groups of students who learn using quantum teaching models assisted by interactive multimedia and students who learn to use conventional learning. The type of research used is a quasi-experimental design with non-equivalent control group design. The study population included all classes V SDN Gugus V Jenderal Sudirman Subdistrict South Denpasar in the even semester as many as 331 students. The research sample was determined by random sampling technique. The sample in this study was VA class SDN 6 Sesetan as many as 45 students as the experimental group and class V SDN 2 Serangan as many as 38 students as the control group. The research data was collected using the filling test method. The collected data was analyzed by $\mathrm{t}$-test. The results of data analysis at a significance level of $5 \%\left(\mathrm{dk}=81\right.$ with $\mathrm{t}_{\text {count }}=3.70$ and $\left.\mathrm{t}_{\text {table }}=2.00\right)$, namely Ho is rejected, and the average value of students learning to use quantum teaching models assisted by interactive multimedia, namely 80.24 and students who learn to use conventional learning, which is 74.84 . Then there is a significant difference in writing skills between groups of students who learn to use quantum teaching models assisted by interactive multimedia and students who learn to use conventional learning. Thus, it can be concluded that the quantum teaching model assisted by interactive multimedia influences the writing skills of fifth grade students of SDN Gugus V Jenderal Sudirman, South Denpasar Subdistrict, 2018/2019 academic year.
\end{abstract}

Keywords: Quantum Teaching, Writing Skills, Multimedia 


\section{Pendahuluan}

Pembelajaran merupakan suatu proses menciptakan kondisi yang kondusif agar terjadi interaksi komunikasi antara guru, peserta didik dan komponen pembelajaran lainnya untuk mencapai tujuan pembelajaran. Hal tersebut sejalan dengan pandangan Hamalik (dalam Rusman, 2017:85) menyatakan bahwa "pembelajaran sebagai suatu kombinasi yang tersusun, meliputi unsur manusia, materil, fasilitas, perlengkapan dan prosedur yang saling mempengaruhi untuk mencapai tujuan pembelajaran". Pelaksanaan pembelajaran pada Kurikulum 2013 di SD saat ini dilakukan melalui pembelajaran dengan pendekatan tematik terpadu dari kelas I sampai kelas VI. Tercantum dalam Permendikbud No.57 (2014:18) "pembelajaran tematik terpadu merupakan pendekatan pembelajaran yang mengintegrasikan berbagai kompetensi dari berbagai mata pelajaran ke dalam berbagai tema”. Salah satu mata pelajaran pada pembelajaran tematik terpadu adalah bahasa Indonesia.

Menurut Rahayu (2015) Bahasa Indonesia merupakan media komunikasi utama masyarakat Indonesia. Ada kalanya Bahasa Indonesia menjadi bahasa kedua, setelah bahasa ibunya oleh karena masyarakat Indonesia berada dalam tataran situasi bilingual atau multilingual. Hal itu juga dipengaruhi oleh perkembangan zaman, dan fenomena berbahasa sesuai usia dan lingkungan pemakainya pada suatu masa tertentu

Bahasa Indonesia adalah salah satu mata pelajaran yang penting untuk dipelajari. Pembelajaran bahasa Indonesia, terutama di SD tidak terlepas dari empat komponen keterampilan berbahasa. Setiap keterampilan tersebut sangat erat kaitannya satu sama lain. Empat komponen keterampilan berbahasa tersebut yaitu "keterampilan menyimak, keterampilan berbicara, keterampilan membaca, dan keterampilan menulis" (Tarigan, 2013:1). Keempat komponen keterampilan berbahasa pada dasarnya merupakan suatu kesatuan yang erat pula berhubungan dengan proses-proses dalam mendasari bahasa. Bahasa seseorang mencerminkan pikirannya. "Semakin terampil seseorang berbahasa, semakin cerah dan jelas pula jalan pikirannya" (Tarigan, 2013:1). Hal ini sependapat dengan pendapat Sari (2016) Pada prinsipnya tujuan pembelajaran bahasa Indonesia bagi para siswa adalah untuk menguasai keterampilan berbahasa yang meliputi empat aspek keterampilan berbahasa, yaitu : (1) keterampilan menyimak; (2) keterampilan berbicara; (3) keterampilan membaca; dan (4) keterampilan menulis. Keempat keterampilan berbahasa ini memiliki hubungan yang sangat erat, karena salah satu dari keterampilan ini tidak bisa berdiri sendiri tanpa ditunjang oleh keterampilan lainnya.

Keterampilan dapat diperoleh dan dikuasai dengan praktik dan banyak pelatihan. Melatih keterampilan berbahasa berarti pula melatih keterampilan berpikir. Salah satu keterampilan berbahasa yang harus dimiliki oleh seorang siswa adalah keterampilan menulis. Berdasarkan Permendikbud No.27 tahun 2017 tentang Standar Kompetensi Lulusan Kursus menjelaskan pengertian dari keterampilan menulis adalah "suatu kemampuan dalam memahami dan mengemukakan gagasan dalam bentuk tulisan yang sesuai dengan konteks dan tujuan”.

Berkaitan dengan uraian di atas terdapat definisi tentang keterampilan menulis yang diungkapkan oleh para ahli. Menurut Tarigan (dalam Susanto 2013:247), berpendapat bahwa "menulis merupakan suatu kegiatan yang produktif dan ekspresif". Dalam kegiatan menulis ini, penulis harus terampil memanfaatkan grafolegi, struktur bahasa dan kosakata. Keterampilan menulis ini tidak akan datang secara otomatis, tetapi harus melalui latihan dan praktik yang banyak dan teratur. Menulis adalah kegiatan produktif dengan menggunakan tulisan. Menulis sebagai keterampilan seseorang (individu) untuk mengomunikasikan pesan dalam sebuah tulisan. Menulis dapat dikatakan sebagai suatu keterampilan berbahasa yang paling rumit diantara jenis-jenis keterampilan berbahasa lainnya, karena "menulis bukanlah sekadar menyalin kata-kata dan kalimat-kalimat melainkan juga mengembangkan dan menuangkan pikiran-pikiran" (Mulyati, 2008:1.13). Menulis sangat penting bagi pendidikan karena memudahkan para pelajar berpikir. Mengimplementasikan pembelajaran agar sesuai dengan tujuan dari pendekatan saintifik dan peraturan pemerintah tersebut maka guru diberikan kebebasan untuk memanfaatkan berbagai model pembelajaran.

Dalam proses pembelajaran, "terdapat empat komponen penting yang berpengaruh bagi keberhasilan belajar siswa yaitu: bahan ajar, suasana belajar, media dan sumber belajar, serta guru sebagai subjek pembelajaran" (Miftahul, 2010 : 16). Komponen-komponen tersebut dikemas dalam sebuah model pembelajaran. "Model pembelajaran merupakan suatu rencana atau pola yang dapat digunakan untuk membentuk kurikulum, merancang bahan-bahan pembelajaran dan membimbing pembelajaran dikelas atau yang lain" (Rusman, 2017:244). Guru sebaiknya dapat memilih model pembelajaran yang sesuai, efektif dan efesien untuk mencapai tujuan pembelajaran dan keberhasilan siswa yang diharapkan.

Media pembelajaran adalah komponen yang berpengaruh pada keberhasilan suatu pembelajaran. "Hakekatnya media pembelajaran sebagai wahana untuk menyampaikan pesan atau informasi dari sumber pesan dan diteruskan pada penerima" (Rusman, 2017:215). Media dan sumber belajar yang digunakan harus sesuai dengan tujuan pembelajaran yang telah ditetapkan dan dapat merangsang anak untuk lebih memperhatikan dan berupaya mengembangkan apa yang telah diterimanya. "Penggunaan media pembelajaran bukan merupakan fungsi tambahan, tetapi memiliki fungsi tersendiri sebagai sarana bantu untuk mewujudkan situasi pembelajaran yang lebih efektif" (Susilana, 2007:9). Oleh karena itu, guru sebagai subjek dalam pembelajaran harus dapat memilih dan menyajikan media pembelajaran yang tepat dan aktif sehingga bahan pelajaran yang disampaikan dapat diterima dan dikembangkan siswa dengan baik. 
Pengembangan kreativitas guru agar mampu menciptakan suasana yang kondusif serta pembelajaran yang tidak monoton dan membosankan sangat perlu dilakukan. Selain itu, terciptanya kelas yang mengembangkan potensi siswa dan membangkitkan keaktifan siswa di dalam kelas mampu menjadikan pembelajaran menjadi lebih menarik serta pembelajaran tidak hanya berpusat pada guru. Dengan meningkatnya keaktifan siswa di dalam kelas, siswa dapat menggali informasi dari pengalamannya sendiri serta kemampuan dan kepercayaan diri siswa di dalam kelas semakin meningkat.

Salah satu cara untuk mewujudkan hal tersebut adalah dengan cara menerapkan model-model pembelajaran yang menarik dan efisien serta penggunaan media pembelajaran yang sesuai. Model-model pembelajaran berperan membantu proses belajar dalam membangkitkan kembali aktivitas siswa di dalam kelas dan potensi-potensi siswa dapat tersalurkan dengan baik. Saat ini banyak model-model pembelajaran dan media pembelajaran yang bisa diterapkan di dalam kelas guna mengembangkan pembelajaran dan menciptakan suasana belajar yang menyenangkan sekaligus tidak membosankan.

Berdasarkan pengalaman PPL-Real pada bulan September 2018, dan observasi sekaligus wawancara pada hari Kamis, 29 November 2018 dengan kepala sekolah dan guru kelas V di SDN Gugus V Jenderal Sudirman Kecamatan Denpasar Selatan tahun ajaran 2018/2019, ditemukan beberapa permasalahan yang melatarbelakangi rancangan penelitian ini. Permasalahan tersebut adalah sekolah belum melakasanakan pembelajaran dan penggunaan media pembelajaran secara maksimal. Pelaksanaan pembelajaran masih dilaksanakan secara teacher centre atau berpusat pada guru. Hal tersebut menyebabkan pembelajaran menjadi membosankan dan para siswa menjadi kurang termotivasi dalam mengikuti pembelajaran di kelas. Hal ini juga berdampak terhadap keterampilan menulis Indonesia siswa.

Pengumpulan data melalui observasi tersebut, menyatakan bahwa keterampilan menulis siswa dalam mata pelajaran bahasa Indonesia perlu ditingkatkan, hal tersebut terlihat pada dominan siswa yang belum menulis sesuai dengan kaidah yang ada. Perlunya peningkatan dari keterampilan siswa dalam menulis tersebut dikarenakan siswa sulit untuk menemukan ide, minimnya penggunaan media oleh guru, serta kurangnya inovasi model pembelajaran yang digunakan oleh guru yang hanya cenderung menggunakan metode ceramah dan pemberian tugas, sehingga siswa menjadi bosan.

Pemberian inovasi perlu dilakukan dalam pembelajaran untuk dapat meningkatkan keterampilan menulis siswa. Salah satu inovasi pembelajaran yang dapat dilakukan adalah dengan menggunakan model pembelajaran yang tepat dan dapat berpengaruh baik yakni model quantum teaching. "Quantum teaching adalah model pembelajaran yang menawarkan ide baru tentang bagaimana menciptakan lingkungan yang jauh lebih baik serta yang menjanjikan bagi pelajar dan mendukung mereka dalam proses pembelajaran agar tidak terjadi ketidakseimbangan” (Miftahul, 2010:19). Model pembelajaran kuantum ini berupaya membangkitkan motivasi, kreativitas, dan keterlibatan siswa secara langsung dalam proses pembelajaran.

Suatu model pembelajaran dapat digunakan apabila terdapat keunggulan/kelebihan dari model tersebut dalam pengaplikasiannya. Kelebihan dari pengaplikasian model quantum teaching dinyatakan oleh VosGroendendal (dalam DePorter, 2016 : 248) yaitu, "siswa memperoleh kepercayaan diri, mempelajari cara-cara mengekpresikan diri, dan merasa bersemangat mengenai kemungkinan-kemungkinan potensi diri mereka". Pendapat tersebut sejalan dengan pendapat dari Shoimin (2014 : 145), yang menyatakan bahwa kelebihan dari model quantum teaching yaitu; 1) Dapat membimbing peserta didik ke arah berpikir yang sama dalam satu saluran pikiran yang sama; 2) Karna quantum teaching lebih melibatkan siswa saat proses pembelajaran, perhatian murid dapat dipusatkan kepada hal-hal yang dianggap penting oleh guru sehingga hal yang penting itu dapat diamati secara teliti; 3) Karena gerakan dan proses dipertujukkan maka tidak memerlukan keteranganketerangan yang banyak; 4) Proses pembelajaran menjadi lebih nyaman dan menyenangkan; 5) Siswa dirangsang untuk aktif mengamati, menyesuaikan antara teori dengan kenyataan, dan dapat mencoba melakukanya sendiri. 6) Karena model pembelajaran quantum teaching membutuhkan kreativitas dari seorang guru untuk merangsang keinginan bawaan siswa untuk belajar, secara tidak langsung guru terbiasa unuk berpikir kreatif setiap harinya; 7) Pelajaran yang diberikan oleh guru mudah diterima atau dimengerti oleh siswa.

Kelebihan dari quantum teaching lainnya dinyatakan oleh Miftahul (2010 : 145), sebagai berikut. Quantum teaching merangkaikan yang paling baik dari yang terbaik menjadi sebuah paket multisensori, multi kecerdasan, dan kompatibel dengan otak, yang pada akhirnya akan meningkatkan kemampuan guru agar dapat merangsang anak untuk berprestasi. Cara ini dapat memaksimalkan usaha pengajaran guru melalui perkembangan hubungan, pengubahan belajar, dan penyampaian kurikulum serta menciptakan lingkungan belajar yang efektif, merancang kurikululum, menyampaikan isi dan memudahkan proses belajar. Model pembelajaran akan lebih sempurna apabila didukung dengan penggunaan media pembelajaran, salah satunya dengan memanfaatkan multimedia interaktif. Selain lebih variatif, multimedia interaktif dapat memaksimalkan interaksi dari siswa secara aktif sehingga dapat menumbuhkan motivasi siswa.

Berdasarkan uraian tersebut, pemilihan model maupun media pembelajaran penting dilakukan untuk membelajarkan siswa di dalam kelas khususnya dalam meningkatkan keterampilan menulis siswa. Untuk itu dilaksanakan penelitian yang berjudul "Pengaruh Model Quantum Teaching Berbantuan Multimedia Interaktif 
Terhadap Keterampilan Menulis Siswa Kelas V SDN Gugus V Jenderal Sudirman Kecamatan Denpasar Selatan Tahun Ajaran 2018/2019”.

\section{Metode}

Pelaksanaan penelitian dilaksanakan di SDN Gugus V Jenderal Sudirman Kecamatan Jenderal Sudirman Kecamatan Denpasar Selatan, yang terdiri dari 5 SD Negeri yaitu SDN 3 Serangan, SDN 6 Sesetan, SDN 13 Sesetan, SDN 2 Serangan dan SDN 2 Sesetan. Pelaksanaan penelitian dilaksanakan pada bulan April 2019 sampai dengan bulan Mei 2019, pada dua sekolah dasar negeri di Gugus V Jenderal Sudirman Kecamatan Denpasar Selatan yang merupakan sampel dalam penelitian ini yaitu SDN 6 Sesetan sebagai kelompok eksperimen dan SDN 2 Serangan sebagai kelompok kontrol. Penelitian pada kelompok eksperimen dan kelompok kontrol, terdiri atas pemberian pretest, pemberian perlakuan sebanyak 6 kali dan pemberian posttest pada kelompok eksperimen dan kelompok kontrol. Jumlah perlakuan yang diberikan telah disesuaikan dengan materi dalam penelitian ini yang telah diatur dalam kurikulum dan silabus.

Rancangan penelitian yang digunakan dalam penelitian ini adalah penelitian kuantitatif dengan desain eksperimen semu (quasi experimental design). Bentuk desain eksperimen semu yang digunakan adalah Nonequivalent Control Group Design. Berdasarkan desain eksperimen semu dengan bentuk non-equivalent control group design, dalam penelitian ini pretest diberikan pada kelompok eksperimen dan kelompok kontrol sebagai penyetaraan kelompok. Selanjutnya pada kelompok eksperimen diberikan perlakuan berupa model quantum teaching berbantuan multimedia interaktif, sedangkan pada kelompok kontrol tidak diberikan perlakuan atau dengan kata lain dibelajarkan dengan pembelajaran konvensional. Setelah diberikan perlakuan, kelompok eksperimen dan kelompok kontrol diberikan posttest untuk memperoleh data keterampilan menulis siswa. Dalam desain ini terdapat dua kelompok, yaitu kelompok eksperimen dan kelompok kontrol.

Penelitian ini dilakukan dengan menempuh langkah-langkah yang terdiri dari tiga tahapan yaitu: tahap persiapan, tahap pelaksanaan, dan tahap akhir eksperimen. Langkah-langkah yang dilakukan pada tahap persiapan eksperimen yaitu, menyusun RPP dan sumber belajar (alat peraga, silabus dan kurikulum) yang digunakan selama proses pembelajaran pada kelompok eksperimen, menyusun media untuk kelompok yang akan diteliti, menyusun instrumen penelitian berupa tes objektis bentuk tes isian pada wacana rumpang dan rubrik penilaian keterampilan menulis, mengadakan instrumen penelitian yaitu tes isian pada wacana rumpang dan rubrik penilaian keterampilan menulis.

Kemudian pada tahap pelaksanaan hal yang dilakukan adalah langkah-langkah yang dilakukan pada saat pelaksanaan eksperimen yaitu, menentukan sampel penelitian berupa kelas dari populasi yang tersedia, dari kelas populasi yang tersedia diundi untuk menentukan dua kelas yang diberi pretest untuk diuji kesetaraannya, setelah setara kedua kelas tersebut diundi untuk menentukan kelas eksperimen dan kelas kontrol, selanjutnya penelitian dapat dilaksanakan dengan memberikan perlakuan pada kelas eksperimen berupa model quantum teaching berbantuan multimedia interaktif serta kepada kelas kontrol berupa pembelajaran konvensional. Pada tahap akhir eksperimen hal yang dilakukan adalah memberikan posttest pada akhir penelitian, baik untuk kelompok eksperimen maupun kelompok kontrol serta menganalisis data hasil penelitian dan melakukan uji hipotesis.

Dalam penelitian ini untuk menentukan subjek yang diteliti adalah menentukan populasi yang akan diteliti. Menurut Agung (2014:87) “populasi adalah keseluruhan objek dalam suatu penelitian”. Sejalan dengan pendapat tersebut Sugiyono (2011:80) menyatakan bahwa "populasi adalah wilayah generalisasi yang terdiri atas: objek/subjek yang mempunyai kualitas dan karakteristik tertentu yang ditetapkan oleh peneliti untuk dipelajari dan kemudian ditarik kesimpulannya". Berdasarkan kedua pendapat di atas, dapat dirangkum populasi adalah keseluruhan objek suatu penelitian yang mempunyai kualitas dan karakteristisk tertentu yang ditetapkan oleh peneliti. Populasi penelitian ini adalah seluruh siswa kelas V SDN Gugus V Jenderal Sudirman Kecamatan Denpasar Selatan tahun ajaran 2018/2019 yang berjumlah 331 orang siswa.

Setelah mengetahui populasi dari penelitian, langkah berikutnya yaitu penentuan sampel penelitian. "Sampel adalah bagian dari jumlah dan karakteristik yang dimiliki oleh populasi tersebut" (Sugiyono, 2011:118). Menurut Agung (2014:87) "sampel ialah bagian dari populasi yang diambil dengan teknik tertentu dan dianggap mewakili seluruh populasi”. Teknik yang digunakan dalam pengambilan sampel pada penelitian ini adalah teknik random sampling dengan kelasnya yang diacak, sehingga setiap kelas memiliki peluang yang sama untuk menjadi sampel penelitian. Sampel dalam penelitian ini adalah kelas VA SDN 6 Sesetan sebanyak 
45 siswa sebagai kelompok eksperimen dan kelas V SDN 2 Serangan sebanyak 38 siswa sebagai kelompok kontrol.

Dalam penelitian ini terdapat dua variabel, yaitu variabel bebas dan variabel terikat. "Variabel bebas yaitu satu atau lebih dari variabel-variabel yang sengaja dipelajari pengaruhnya terhadap variabel terikat" (Agung, 2014 : 42). Menurut Sugiyono (2011 : 39) “variabel bebas merupakan variabel yang mempengaruhi atau yang menjadi sebab perubahannya atau timbulnya variabel terikat". Berdasarkan paparan para ahli tersebut dapat dirangkum bahwa variabel bebas merupakan variabel yang mempengaruhi variabel terikat atau variabel yang dipelajari pengaruhnya terhadap variabel terikat. Variabel bebas dalam penelitian ini adalah model quantum teaching berbantuan multimedia interaktif.

Menurut Sugiyono (2011 : 38) "variabel terikat merupakan variabel yang dipengaruhi atau yang menjadi akibat, karena adanya variabel bebas". "Variabel terikat yaitu variabel yang keberadaannya atau munculnya bergantung pada variabel bebas" (Agung, 2014 : 43). Berdasarkan paparan para ahli tersebut dapat dirangkum bahwa variabel terikat adalah variabel yang dipengaruhi keberadaannya yang bergantung pada variabel bebas. Variabel terikat dalam penelitian ini adalah keterampilan menulis.

Data yang dikumpulkan dalam penelitian ini adalah data tentang keterampilan menulis siswa kelas V SDN Gugus V Jenderal Sudirman kecamatan Denpasar Selatan tahun ajaran 2018/2019. Metode pengumpulan data yang digunakan adalah metode tes. Menurut Arikunto (2013:67) "Tes merupakan alat atau prosedur yang digunakan untuk mengetahui atau mengukur sesuatu dalam suasana, dengan cara dan aturan-aturan yang sudah ditentukan". Jenis tes keterampilan menulis yang digunakan untuk menilai keterampilan menulis siswa pada aspek psikomotor adalah suatu tes kompetensi menulis yaitu tes isian (completion test) pada wacana rumpang.

Menurut Arikunto (2013 : 190), "completion test biasa disebut dengan istilah tes isian, tes menyempurnakan, atau tes melengkapi". Tes isian pada wacana rumpang terdiri atas kalimat-kalimat berangkai yang terdapat bagian-bagiannya yang dihilangkan. Bagian yang dihilangkan atau yang harus diisi oleh siswa ini merupakan pengertian yang diminta dari murid. Sebelum tes diberikan kepada kelompok eksperimen dan kelompok kontrol terlebih dahulu dilakukan uji instrumen. Pengujian terhadap instrumen penelitian digunakan untuk mendapatkan gambaran secara empirik apakah instrumen layak digunakan sebagai instrumen penelitian. Dalam analisis uji validitas menggunakan korelasi product moment diperoleh 13 butir soal valid dari 15 soal yang disusun. Setelah dilakukannya uji validitas, dengan demikian instrumen pada penelitian ini dapat dilakukan uji reliabilitas dengan rumus alpha cronbach $\left(\mathrm{r}_{11}\right)$. Uji reliabilitas dilakukan pada soal yang valid saja dan diperoleh $r_{11}=0,65$ dengan tingkat reliabilitas tinggi.

Dalam penelitian ini data yang terkumpul akan dianalisis menggunakan metode analisis statistik deskriptif dan metode analisis statistik inferensial. Analisis data deskriptif merupakan analisis yang dipakai untuk menganalisis data dengan mendeskripsikan atau menggambarkan data-data yang sudah dikumpul. "Statistik deskriptif adalah suatu cara pengolahan data yang dilakukan dengan jalan menerapkan rumus-rumus statistik deskriptif untuk menggambarkan suatu objek/variabel tertentu, sehingga diperoleh kesimpulan umum" (Agung, 2014 : 110). Statistik deskriptif digunakan untuk menganalisis data keterampilan menulis pada kelompok eksperimen dan kelompok kontrol, statistik deskriptif yang dipergunakan yaitu, mean, standar deviasi, varians. Analisis statistik inferensial adalah cara pengolahan data yang dilakukan dengan jalan menerapkan rumus-rumus statistik inferensial untuk menguji suatu hipotesis penelitian yang diajukan peneliti dan kesimpulan ditarik berdasarkan pengujian terhadap hipotesis (Agung, 2014 : 110). Teknik analisis data yang dilakukan adalah uji hipotesis menggunakan uji-t, sebelum dilakukan uji hipotesis, terlebih dahulu dilakukan uji prasyarat analisis data berupa uji normalitas sebaran data dan uji homogenitas varians, apabila data berdistribusi normal dan homogen maka dilanjutkan dengan analisis statistik parametrik dengan teknik uji-t dengan rumus polled varians, Dengan kriteria pengujian jika harga $t_{\text {hitung }} \leq t_{\text {tabel }}$, maka Ho diterima, dan jika harga $t_{\text {hitung }}>t_{\text {tabel }}$ maka Ho ditolak. Pada taraf signifikan 5\% dengan $\mathrm{dk}=\mathrm{n} 1+\mathrm{n} 2-2$.

\section{Hasil dan Pembahasan}

Penelitian ini merupakan penelitian yang berbentuk quasi experiment atau eksperimen semu yang menggunakan rancangan non-equivalent control group design yang dianalisis menggunakan uji-t. Objek dalam penelitian ini adalah keterampilan menulis siswa kelas V SDN Gugus V Jenderal Sudirman Denpasar Selatan Tahun Ajaran 2018/2019 yang belajar menggunakan model quantum teaching berbantuan multimedia interaktif dan yang belajar menggunakan pembelajaran konvensional. 
Setelah mengetahui populasi dari penelitian, langkah berikutnya yaitu penentuan sampel penelitian. "Sampel adalah bagian dari jumlah dan karakteristik yang dimiliki oleh populasi tersebut" (Sugiyono, 2011:118). Menurut Agung (2014:87) "sampel ialah bagian dari populasi yang diambil dengan teknik tertentu dan dianggap mewakili seluruh populasi”.

Berdasarkan pendapat tersebut, dapat dirangkum sampel adalah bagian dari populasi yang diambil secara acak menggunakan teknik tertentu/teknik sampling dan dianggap mewakili seluruh populasi. Dalam pemilihan sampel penelitian ini tidak dilakukan pengacakan individu, karena tidak bisa mengubah kelas yang telah terbentuk sebelumya dan tanpa ada campur tangan peneliti.

Teknik pengambilan sampel pada penelitian ini adalah teknik random sampling. Random sampling adalah "pengambilan anggota sampel dari populasi dilakukan secara acak tanpa memperhatikan strata yang ada dalam populasi itu" (Sugiyono, 2011:120). Dalam penelitian ini teknik yang digunakan yaitu pengambilan sampel secara acak. "Secara teoretis, semua anggota dalam populasi mempunyai probabilitas atau kesempatan yang sama untuk dipilih menjadi sampel” (Sukardi, 2008:58). Sehubungan dengan pernyataan tersebut, dalam penelitian ini setiap kelas memiliki hak yang sama dan mendapatkan kesempatan dipilih menjadi sampel yang dilakukan dengan cara tiga kali pengundian. Pertama, dilakukan pengundian untuk mendapatkan dua SD dengan menuliskan nama tiap-tiap SDN Gugus V Jenderal Sudirman pada kertas kemudian digulung. Pada penelitian ini didapatkan 2 SDN yaitu SDN 6 Sesetan dan SDN 2 Serangan. Dikarenakan SDN 6 Sesetan memiliki kelas pararel yang terdiri dari kelas VA dan VB, maka pengundian tahap kedua dilakukan untuk menentukan perwakilan dari SDN 6 Sesetan. Pengundian tahap kedua ini menghasilkan kelas VA SDN 6 Sesetan. Setelah 2 kelas diperoleh dilanjutkan dengan memberikan pretest kepada 2 kelas tersebut, pretest diberikan untuk memperoleh nilai keterampilan menulis yang menjadi tolak ukur dalam penyetaraan kelompok.

Teknik penyetaraan yang digunakan dalam penelitian ini adalah teknik uji-t. Sebelum melakukan uji-t, terlebih dahulu dilakukan uji prasyarat analisis terhadap hasil pretest, berupa uji normalitas data dan uji homogenitas varians. Apabila sampel sudah setara, maka dilakukan pengundian tahap ketiga untuk menentukan kelompok eksperimen dan kelompok kontrol. Setelah dilakukan pengundian, kelompok eksperimen diberikan perlakuan model quantum teaching berbantuan multimedia interaktif sedangkan kelompok kontrol dibelajarkan dengan pembelajaran konvensional. Berdasarkan hasil analisis uji kesetaraan sampel penelitian antar kelas VA SDN 6 Sesetan dan kelas V SDN 2 Serangan, diperoleh $t_{\text {hitung }}=0,32 \leq t_{\text {tabel }}=2,00$. Dengan demikian kedua kelas dinyatakan setara. Hal tersebut berarti kedua kelas dapat dijadikan sebagai sampel penelitian. Selanjutnya dilakukan pengundian dari dua sampel setara untuk memilih kelas yang digunakan sebagai kelompok kontrol dan kelompok eksperimen. Hasil akhir pengundian ditetapkan siswa kelas VA SDN 6 Sesetan sebagai kelas eksperimen dan kelas V SDN 2 Serangan sebagai kelas kontrol. Kelompok eksperimen belajar menggunakan model quantum teaching berbantuan multimedia interaktif dan kelompok kontrol belajar menggunakan pembelajaran konvensional sebanyak $6 \mathrm{kali}$, dan pada akhir penelitian kelompok eksperimen dan kelompok kontrol diberikan posttest, hasil posttest kemudian dianalisis menggunakan uji-t.

Berdasarkan perhitungan uji-t, diperoleh $\mathrm{t}_{\text {hitung }}=3,70$ dan pada taraf signifikansi $5 \%$ dengan dk $=(45+$ $38-2)=81$ diperoleh $t_{\text {tabel }}=2,00$. Dengan demikian, nilai $t_{\text {hitung }} 3,70>2,00$, sehingga Ho (hipotesis nol) yang berbunyi tidak terdapat perbedaan yang signifikan keterampilan menulis antara kelompok siswa yang dbelajarkan menggunakan model quantum teaching berbantuan multimedia interaktif dan kelompok siswa yang dibelajarkan menggunakan pembelajaran konvensional pada kelas V SDN Gugus V Jenderal Sudirman Kecamatan Denpasar Selatan tahun ajaran 2018/2019 ditolak. Berikut disajikan rekapitulasi hasil analisis data dengan menggunakan uji-t pada Tabel 1.

Tabel 1. Hasil Uji Hipotesis Penelitian

\begin{tabular}{clcccccc}
\hline No & \multicolumn{1}{c}{ Sampel Penelitian } & $\mathbf{N}$ & $\mathbf{d k}$ & $\mathbf{M e}$ & $\mathbf{t}_{\text {hitung }}$ & $\mathbf{t}_{\text {tabel }}$ & Kesimpulan \\
\hline 1 & Eksperimen & 45 & \multirow{2}{*}{81} & 80,24 & \multirow{2}{*}{3,70} & \multirow{2}{*}{2,00} & \multirow{2}{*}{$\mathrm{H}_{\mathrm{O}}$ ditolak } \\
2 & Kontrol & 38 & & 74,84 & & & \\
\hline
\end{tabular}

Hal ini berarti terdapat perbedaan yang signifikan keterampilan menulis antara kelompok eksperimen dan kelompok kontrol pada kelas V SDN Gugus V Jenderal Sudirman Kecamatan Denpasar Selatan tahun ajaran 2018/2019. Dengan demikian model quantum teaching berbantuan multimedia interaktif berpengaruh terhadap keterampilan menulis siswa kelas V SDN Gugus V Jenderal Sudirman Kecamatan Denpasar Selatan Tahun Ajaran 2018/2019.

Perolehan hasil perhitungan analisis data yang dilakukan menunjukkan bahwa nilai rata-rata kelompok siswa yang mengikuti pembelajaran menggunakan model quantum teaching berbantuan multimedia interaktif (X 
$=80,24)$ dan siswa yang mengikuti pembelajaran konvensional $(\mathrm{X}=74,84)$ memilki perbedaan sebesar 5,4. Dengan demikian, terdapat perbedaan yang signifikan keterampilan menulis antara kelompok eksperimen dan kelompok kontrol pada kelas V SDN Gugus V Jenderal Sudirman Kecamatan Denpasar Selatan tahun ajaran $2018 / 2019$.

Berdasarkan hasil temuan tersebut, setelah diberikan perlakuan berupa pembelajaran pembelajaran dengan menggunakan model quantum teaching berbantuan multimedia interaktif dan mengikuti pembelajaran konvensional diperoleh keterampilan yang berbeda. Hal ini dapat dilihat juga dari nilai rata-rata kelompok siswa yang mengikuti pembelajaran menggunakan model quantum teaching berbantuan multimedia interaktif lebih tinggi dibandingkan dengan rata-rata siswa yang mengikuti pembelajaran konvensional. Perbedaan keterampilan dengan perolehan nilai rata-rata yang lebih tinggi pada kelompok eksperimen dibandingkan kelompok kontrol disebabkan oleh perlakuan berupa model quantum teaching berbantuan multimedia interaktif dalam keterampilan menulis diberikan pada kelompok eksperimen.

Pada kelompok eksperimen, kegiatan pembelajaran dalam muatan materi teks narasi menggunakan model quantum teaching berbantuan multimedia interaktif berjalan dengan optimal dan kondusif. Hal ini disebabkan karena model quantum teaching berbantuan multimedia interaktif merupakan suatu inovasi pembelajaran yang menekankan siswa untuk lebih aktif dan percaya diri mengekspresikan pikiran dalam bentuk tulis maupun lisan dan multimedia interaktif sebagai media yang mumpuni. Selama kegiatan pembelajaran, siswa dalam kegiatan pembelajaran dirangsang untuk aktif mengamati, menyesuaikan antara teori dengan kenyataan sehingga dapat mendemonstrasikan secara mandiri. Siswa menjadi lebih aktif karena kegiatan pembelajaran menggunakan model quantum teaching berbantuan multimedia interaktif menciptakan lingkungan belajar yang menarik dan interaktif dengan multimedia interaktif sebagai media pembelajaran dan memberikan kebebasan siswa untuk mengemukakan pendapat dan melatih keterampilan berbahasanya terutama dalam keterampilan menulis.

Hasil temuan pada penelitian ini memiliki persamaan dengan penelitian sebelumnya yang relevan dan memperkuat hasil penelitian yang diperoleh. Hal tersebut didukung oleh penelitian yang relevan, yakni penelitian yang dilakukan oleh Supramono (2016), pada siswa kelas III SD YPS Lawaweu Kecamatan Nuha Kabupaten Luwu Timur. Dengan meneliti Pengaruh Model Quantum Teaching terhadap hasil belajar IPA yang berpengaruh signifikan. Selain itu penggunaan media juga didukung penelitian yang dilakukan oleh Arfiyani (2015) pada siswa SD. Dengan meneliti Pengimplementasian Media Pembelajaran Berbasis Multimedia Interaktif pada Mata Pelajaran Matematika dengan hasil penelitian diperoleh peningkatan aspek minat belajar pada mata pelajaran matematika. Namun dalam penelitian ini dilakukan penelitian tentang pengaruh model quantum teaching berbantuan multimedia interaktif terhadap keterampilan menulis siswa. Dengan demikian pemebelajaran menggunakan model quantum teaching berbatuan multimedia interaktif pada penelitian ini memiliki keunggulan yakni dapat membuat siswa menjadi lebih aktif dalam pembelajaran dan meningkatkan kemampuan berpikir siswa dengan memberikan pengalaman yang berkesan bagi siswa didukung oleh peran guru dalam penyajian materi, tidak adanya diskriminasi, serta pengakuan atas usaha yang dilakukan.

\section{Simpulan}

Berdasarkan hasil analisis data keterampilan menulis kelompok siswa yang belajar menggunakan model quantum teaching berbantuan multimedia interaktif pada siswa kelas V SDN Gugus V Jenderal Sudirman Denpasar Selatan Tahun Ajaran 2018/2019, diperoleh rerata keterampilan menulis siswa kelas VA SDN 6 Sesetan tahun ajaran 2018/2019 setelah belajar dengan menggunakan model quantum teaching berbantuan multimedia interaktif sebesar 80,24.

Sedangkan berdasarkan hasil analisis data keterampilan menulis kelompok siswa yang belajar menggunakan pembelajaran konvensional pada siswa kelas V SDN Gugus V Jenderal Sudirman Denpasar Selatan Tahun Ajaran 2018/2019, diperoleh nilai rerata keterampilan menulis siswa kelas V SDN 2 Serangan tahun ajaran 2018/2019 setelah belajar dengan menggunakan pembelajaran konvensional sebesar 74,84.

Dengan demikian, dapat dinyatakan bahwa terdapat perbedaan yang signifikan keterampilan menulis siswa yang belajar dengan menggunakan model quantum teaching berbantuan multimedia interaktif dan yang belajar dengan menggunakan pembelajaran konvensional pada siswa kelas V SDN Gugus V Jenderal Sudirman Kecamatan Denpasar Selatan Tahun Ajaran 2018/2019. Hal ini terbukti dari hasil analisis uji-t keterampilan menulis siswa yang belajar dengan menggunakan model quantum teaching berbantuan multimedia interaktif dan kelompok siswa yang belajar dengan menggunakan pembelajaran konvensional pada siswa kelas V SDN Gugus V Jenderal Sudirman Kecamatan Denpasar Selatan Tahun Ajaran 2018/2019 diperoleh $t_{\text {hitung }}=3,70$ dan pada taraf signifikansi $5 \%$ dengan $\mathrm{dk}=(45+38-2)=81$ diperoleh ttabel $=2,00$. Dengan demikian, nilai $\mathrm{t}_{\text {hitung }} 3,70>$ 2,00 , sehingga Ho atau hipotesis nol ditolak. Hal ini berarti terdapat perbedaan yang signifikan keterampilan menulis antara kelompok siswa yang belajar dengan menggunakan model quantum teaching berbantuan multimedia interaktif dan kelompok siswa yang belajar dengan menggunakan pembelajaran konvensional pada kelas V SDN Gugus V Jenderal Sudirman Denpasar Selatan tahun ajaran 2018/2019. Dengan demikian, dapat 
disimpulkan bahwa model quantum teaching berbantuan multimedia interaktif berpengaruh terhadap keterampilan menulis siswa kelas V SDN Gugus V Jenderal Sudirman Kecamatan Denpasar Selatan tahun ajaran 2018/2019.

Berdasarkan hasil penelitian, pembahasan dan simpulan, maka diajukan beberapa saran kepada beberapa pihak sebagai berikut. (1) Kepada guru diharapkan agar lebih kreatif dan inovatif untuk meningkatkan minat belajar serta memberikan kesempatan yang lebih besar kepada siswa untuk berpartisipasi dalam pembelajaan di dalam kelas dengan menggunakan model quantum teaching berbantuan multimedia interaktif sehingga tercipta pembelajaran yang menarik, interaktif dan bermakna bagi siswa. (2) Kepada kepala sekolah diharapkan agar model pembelajaran quantum teaching berbantuan multimedia interaktif dapat dijadikan alternatif perbaikan kualitas pembelajaran dan mencapai tujuan pembelajaran yang diharapkan. (3) Kepada peneliti lain disarankan agar hasil penelitian ini digunakan sebagai referensi untuk melaksanakan penelitian selanjutnya atau menemukan inovasi kegiatan pembelajaran lainnya yang bermakna dan berdampak positif bagi siswa.

\section{Daftar Pustaka}

Agung, Gede. 2014. Buku Ajar Metodelogi Penelitian Pendidikan. Malang : Aditya Media Publishing. Arfiyani. 2015. "Pengimplementasian Media Pembelajaran Berbasis Multimedia Interaktif Pada Mata Pelajaran Matematika Di Sekolah Dasar" Tersedia pada : http://ejournal.uksw.edu/scholaria/article/view/22 (diakses pada 26 Desember 2018).

Arikunto, Suharsimi. 2013. Dasar-Dasar Evaluasi Pendidikan. Jakarta : Bumi Aksara.

DePorter, Bobbi. 2010. Quantum Teaching. Bandung : PT Mizan Pustaka.

Miftahul. 2010. Quantum Teaching (Buku Pintar dan Praktis). Yogjakarta : Diva Press.

Mulyati, dkk. 2008. Keterampilan Berbahasa Indonesia SD. Jakarta : Universitas Terbuka.

Permendikbud No. 27 Tahun 2017 tentang Standar Kompetensi Lulusan Kursus. 2017. Jakarta: Dapartemen Pendidikan dan Kebudayaan.

Permendikbud No. 57 Tahun 2014 tentang Kurikulum 2013 Sekolah Dasar/Madrasah Ibtidaiyah. 2014. Jakarta: Dapartemen Pendidikan dan Kebudayaan.

Rahayu, Arum Putri. 2015. Menumbuhkan Bahasa Indonesia yang Baik dan Benar dalam Pendidikan dan Pengajaran. Jurnal Paradigma Volume 2, Nomor 1, Hal. 1-15. Tersedia Pada: http://ejournal.kopertais4.or.id/mataraman/index.php/paradigma/article/view/886/644. (diakses pada 5 Januari 2019).

Rusman. 2017. Belajar \& Pembelajaran Berorientasi Standar Proses Pendidikan. Jakarta : Kencana.

Sari, Santika Damayanti, Wagiran, Imam Baehaqie. 2016. Peningkatan Keterampilan Menulis Teks Berita Melalui Model Think Talk Write dengan Pemanfaatan Media Kliping Foto Jurnalistik pada Siswa Kelas VIII C SMP Negeri 8 Batang. Jurnal Pendidikan Bahasa dan Sastra IndonesiaVol. 5 No. 1 Hal. 25-30. Tersedia Pada: http://journal.unnes.ac.id/sju/index.php/jpbsi. (diakses pada 5 Januari 2019).

Shoimin, Aris. 2014. 68 Model Pembelajaran Inovatif dalam Kurikulum 2013. Yogyakarta : Ar-Ruzz Media. Sugiyono. 2011. Metode Penelitian Pendidikan. Bandung: Alfabeta.

Sugiyono. 2013. Metode Penelitan Kuantitatif Kualitatif Dan R\&D. Bandung : Alfabeta.

Supramono. 2016. Pengaruh Model Pembelajaran Kuantum (Quantum Teaching) Terhadap Hasil Belajar IPA Kelas III SD YPS Lawewu Kecamatan Nuha Kabupaten Luwu Timur" Tersedia pada : http://ojs.unm.ac.id/nalar/article/download/2401/1886 (diakses pada 5 Januari 2019).

Susanto, Ahmad. 2013. Teori Belajar dan Pembelajaran di Sekolah Dasar. Jakarta : Prenadamedia Group.

Susilana, dkk. 2007. Media Pembelajaran. Bandung : CV Wacana Prima.

Tarigan, Guntur. 2013. Menulis Sebagai Suatu Keterampilan Berbahasa. Bandung : CV Angkasa. 